\title{
En kvinne med tilbakevendende arteriovenøse tromboser
}

\author{
En 61 år gammel kvinne fikk brystsmerter og forbigående synstap, \\ deretter vansker med bruk av høyre arm og taleforstyrrelser. Tilbake- \\ vendende arteriovenøse tromboser gjorde henne i løpet av fem måneder \\ til en dement og pleietrengende pasient.
}

Se kommentar side 1306

\section{Mirza Jusufovic* \\ mirza.jusufovic@helse-bergen.no \\ Lars Thomassen \\ Anette Storstein \\ Nevrologisk avdeling \\ Svein Rotevatn \\ Hjerteavdelingen \\ Sverre Lehmann \\ Lungeavdelingen \\ Ulrike Waje-Andreassen \\ Nevrologisk avdeling \\ Haukeland universitetssykehus}

\section{* Nåværende adresse:}

Nevrologisk avdeling

Nevroklinikken

Oslo universitetssykehus, Rikshospitalet

En 61 år gammel kvinne hadde migrene med visuell aura med siste anfall ca. ett år før den aktuelle innleggelsen. Fra 15-årsalderen røykte hun ca. 15 sigaretter daglig. En uke før den aktuelle innleggelsen fikk hun brystsmerter som strålte ut mellom skuldrene og synstap på høyre øye som varte $i$ 5-10 minutter. To dager senere oppsøkte hun kiropraktor på grunn av smerter i bryst, nakke og skuldre. Dagen før innleggelsen merket hun igjen synstap på høyre øye med samme varighet. Innleggelsesdagen fikk hun vansker med å bruke høyre hånd, og datteren bemerket taleforstyrrelser. Hun ble innlagt i øyeavdelingen med diagnosen amaurosis fugax. Øyelegen fant ingen aktuell patologi, men reagerte på pasientens påfallende latens og problemer med å ta instruksjoner. Pasienten ble derfor overflyttet til nevrologisk avdeling for videre utredning.

Ved innleggelsen hadde hun blodtrykk 152/ $80 \mathrm{~mm} \mathrm{Hg}$, temperatur $38,5^{\circ} \mathrm{C}$, regelmessig puls 68/min og respirasjonsfrekvens $15 / \mathrm{min}$. Surstoffmetning var $99 \%$ uten oksygen. Ved undersøkelsen hadde hun lett apati og kognitiv svikt, svarte med latens og var ikke orientert for dato. Det ble ikke funnet stenoselyder over halsarteriene eller bilyder over hjertet.
Den somatiske undersøkelsen var ellers upåfallende. Orienterende blodprøver viste CRP $37 \mathrm{mg} / \mathrm{l}$ (normalt < 5), D-dimer > $20 \mathrm{mg} / \mathrm{l}$ (normalt 0,00-0,50) og troponin- $0,5 \mu \mathrm{g} / \mathrm{l}$ (normalt $<0,03$ ), ellers upåfallende funn i blodprøver. Elektrokardiografi (EKG) viste sinusrytme, markert $P$ og T-inversjoner i V4-V6avledningene.

Vanlige symptomer ved akutt hjerneinfarkt i fremre kretsløp er hemiparese, afasi og endret mental funksjon. Ved akutt hjerneinfarkt i bakre kretsløp finnes ofte synsfeltutfall, dobbeltsyn, vertigo, koordinasjonssvikt, kvalme og oppkast. (Sub)febrilitet kan forekomme ved større hjerneinfarkter uten samtidig infeksjon. På grunn av kognitiv svikt, anamnestisk mistanke om afasi, feber og økt D-dimer ble sinusvenetrombose og tumor cerebri vurdert som aktuelle differensialdiagnoser. Andre differansialdiagnoser var encefalitt, hjerneblødning, metabolsk encefalopati, abscess eller andre intrakraniale infeksiøse eller inflammatoriske tilstander. Opplysninger om sannsynlig amaurosis fugax, sammen med opplysninger om kognitiv svikt, problemer å bruke høyre hånd og taleproblemer tydet mer på arterielle emboliske hjerneinfarkter. Computertomografi (CT) eller fortrinnsvis magnetisk resonanstomografi (MR) må utføres som øyeblikkelig hjelp for å kartlegge type og omfang av den akutte skaden $\mathrm{i}$ hjernen.

CT av hjernen ble tatt noen timer etter innleggelsen, og viste sannsynlig ferskt infarkt omkring høyre fissura Sylvii og spredte lavattenuerende forandringer i begge hemisfærer. Spinalpunksjon viste normalt celletall. MR av hjernen etter spinalpunksjon bekreftet iskemiske lesjoner (diffusjonsavvik) i begge cerebrale og cerebellære hemisfærer (fig 1a, fig 1b).

Iskemiske lesjoner i flere cerebrale kargebet er en sterk indikator på embolisk årsak. Cerebralt infarkt som skyldes embolisering fra hjertet til hjernen utgjør om lag ett av fire hjerneinfarkter. Potensielle årsaker til kar- diale embolier er atrieflimmer og atrieflutter, myokardskade etter hjerteinfarkt, dilatert kardiomyopati, endokarditt, myokarditt, mekaniske klaffeproteser, atrieseptumpatologi og intrakardiale svulster. Vår pasient hadde feber, økt CRP og EKG-forandringer, noe som ga mistanke om endokarditt. Endokarditt er en bakteriell infeksjon på hjerteklaffene som kan gi tromber til hjernen og andre organer. Hovedkriteriene for diagnosen endokarditt er to positive blodkulturer med typiske mikroorganismer og karakteristiske ekkokardiografiske funn.

På mistanke om endokarditt ble det dagen etter innleggelsen startet behandling med penicillin 20 millioner enheter per døgn intravenøst etter at blodkulturer var tatt. Transtorakal og transøsofageal ekkokardiografi med ultralydkontrast to dager etter innleggelse viste ikke tegn til endokarditt, men lett venstre ventrikkelhypertrofi, lett nedsatt diastolisk funksjon, noe stort venstre atrium, liten aortainsuffisiens uten hemodynamisk betydning, ingen septumpatologi, spesielt ikke tegn til åpentstående foramen
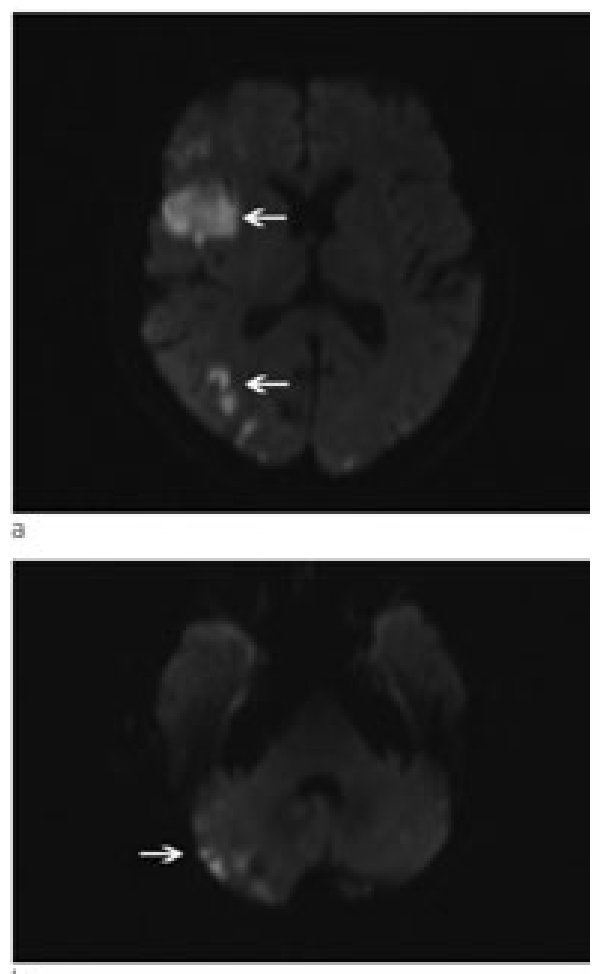

Figur 1 Diffusjonsvektet MR av hjernen ved første innleggelse viser infarkter (pil) a) over og b) under tentoriet 
ovale, men lett arteriosklerose $i$ aorta descendens. En 24-timers EKG-registrering var normal og viste spesielt ikke tegn til atrieflimmer. Blodkultur var negativ.

De ekkokardiografiske undersøkelsene og negative blodkulturene ga ikke holdepunkt for endokarditt. Høy D-dimer, markert P-takk på EKG og en sykehistorie med smerter $i$ thorax ga mistanke om lungeemboli, eventuelt i tillegg dyp venetrombose. Pasienten var respiratorisk ubesværet med normofrekvent respirasjon. Klinisk var det ikke tegn til dyp venetrombose $\mathrm{i}$ underekstremitetene.

CT av thorax to dager etter innkomst viste sikker lungeemboli i høyre overlapp og mulige embolier $i$ segmentarteriene $i$ begge underlappene, forstørrede lymfeknuter mediastinum og litt pleuravæske. Pleuravæsken ble oppfattet som sekundært til lungeemboli. Behandlingen ble forandret fra platehemmende behandling til antikoagulasjonsbehandling med lavmolekylært heparin. CT abdomen, bekken og CT venografi viste pà venstre side dyp venetrombose i alle tre leggvenepar opp til vena poplitea, ingen tromber distalt for dette opp til vena cava inferior. CT av abdomen viste forandringer i milt av usikker etiologi og var ellers upåfallende.

Koagulasjonsprøver, inkludert aktivert protein $C$-resistens, protein $C$ og protein $S$, antitrombin III, C3, C4, homocystein, faktor V-Leiden-mutasjon og protrombingenmutasjon var negative.

Arterioarterielle embolier fører vanligvis til iskemiske lesjoner i ipsilateralt kargebet og ble initialt vurdert som mindre sannsynlig siden det hos pasienten forelå infarkter $i$ flere karområder. Pasienten hadde røykt $i$ mange år og det kunne allikevel foreligge ekstrakranial arteriosklerose med plakkaktivering på grunn av en infeksjonstilstand, selv om det var usannsynlig at dette skulle skje samtidig i alle fire halsarterier.

Dupleks ultralydundersøkelse av ekstrakraniale og intrakraniale arterier viste normale forhold uten tegn til stenoser $i$ carotis- og vertebralisarteriene eller cerebri mediaarteriene. På grunn av anamnestiske opplysninger om brystsmerter, forhøyet troponin-T, negative ekkokardiografiske funn og manglende tegn til ekstrakranial arteriosklerose ble MR av myokard fire dager etter innleggelse utført med spørsmål om myokarditt.

MR av myokard ble beskrevet som forenlig med myokarditt. Fem dager etter innleggelsen ble pasienten overflyttet til hjerteavdelingen for kontinuerlig rytmeovervåking med telemetri. Hun brukte vedvarende penicillin og lavmolekylært heparin og hennes kliniske tilstand var uforandret fra innleggelsen.

Forstørrede lymfeknuter i mediastinum ble først vurdert som mulig reaktiv lymfadeno- pati i sammenheng med myokarditt, men antistoffer mot adenovirus, cytomegalovirus, parvovirus B12, influensavirus, EpsteinBarr-virus, enterovirus, varicella, humant herpes virus 6 og herpes simplex-virus 1 var negative. Muligheten for at hjertesykdom kunne forårsake embolisk hjerneinfarkt, ble vurdert som usannsynlig fordi det verken forelå fokal hypokinesi eller andre tegn til embolikilder i venstre ventrikkel.

Komparentopplysninger fra pasientens datter ved innleggelse ga ikke holdepunkter for at pasienten hadde redusert vekt, blodig urin eller avføring eller andre allmennsymptomer som kunne gi mistanke om kreft. Likevel ga røyking og arteriovenøse tromber og embolier mistanke om kreft.

Kreftmarkørene $\beta_{2}$-mikroglobulin, karsinoembryonalt antigen (CEA), kreftantigen CA125, alfaføtoprotein (AFP) og beta-humant choriongonadotropin ( $\beta-H C G$ ) var negative. Mammografi var negativ. Utredningen så langt hadde ikke påvist bakenforliggende sykdom. Som uavklart ble det anmerket forstørrede lymfeglandler i mediastinum med mulig årsak i infeksjon eller neoplasi.

Dupleks ultralydundersøkelse av ekstrakraniale og intrakraniale arterier hadde vist normale forhold. Gjentatte ekkokardiografiske undersøkelser hadde ikke vist tegn til kardial embolikilde. Revmatolog ble konsultert og differensialdiagnosen vaskulitt ble drøftet. Pasienten ble henvist til CT av torakal aorta og proksimale halsarterier.

CT angiografi av torakal aorta og proksimale halsarterier viste normalkalibrerte kar og ingen tegn til stenoser. En uke etter innkomst startet hun med warfarin med INRmål 2,5, og lavmolekylært heparin ble seponert fem dager etter oppstart av warfarin. Penicillin ble seponert ti dager etter innleggelsen. Pasienten ble utskrevet til en rehabiliteringsinstitusjon tolv dager etter innleggelsen. Hun var da oppegående uten støtte innen- og utendørs, men hadde rom-retnings-vansker, apraksi, afasi og kognitiv reduksjon.

Tre uker etter sykdomsstart fikk pasienten igjen synstap og forverring av rom-retningsvansker. Dette førte til ny innleggelse i nevrologisk avdeling. Klinisk hadde hun høyre homonym hemianopsi, økt apati og apraksi. Hun trengte hjelp til å finne frem $i$ avdelingen. MR av hjernen viste flere nytilkomne iskemiske lesjoner, D-dimer var $>20 \mathrm{mg} / \mathrm{l}$ (normalt 0,00-0,50) og troponin- $T$ hadde økt til 0,27 $\mu \mathrm{g} / \mathrm{l}$ (normalt <0,03). CT av thorax, supplert med CT av abdomen, viste infarkter i nyre og milt, forstørrede binyrer og vekst av lymfeknutene i mediastinum. INR ved innleggelse var 1,6.

Tilfredsstillende oppfølging ved warfarinbehandling stiller store krav både til behandler og til pasient. Ved utelatte doser kan det raskt oppstå terapisvikt og tilbakevendende tromboser. Medisineringen med warfarin var ikke godt nok kontrollert. Men igjen var D-dimerverdien over målbart nivå og kreftsykdom, hematologisk sykdom og systemisk sykdom ble mistenkt som differensialdiagnoser. Troponin var forhøyet og derfor ble utredningen igjen startet med hjerteundersøkelser som mistenkt årsak for arterielle embolier i forskjellige organer.

Ny ekkokardiografi viste uforandrede funn uten fokal hypokinesi, vegetasjoner på hjerteklaffene eller annen kardial embolikilde. Vi avsto fra biopsi av mediastinale lymfeknuter på grunn av antatt høy risiko for tromboser ved seponering av antikoagulasjonsbehandling før prosedyren og fordi lymfeknutene var så små at det var usikkert om man ville få representativt materiale. Undersøkelser utført av øre-nese-hals-lege, hudlege, endokrinolog og øyelege ga ikke holdepunkt for kreft. Sternal beinmargsbiopsi seks uker etter første innleggelse var normal.

Klebrig blodplate-syndrom (sticky platelet syndrome, SPS) kjennetegnes av hyperaktive blodplater som klumper seg ved lave konsentrasjoner av adrenalin og/eller adenosindifosfat, og diagnostikken baseres på aggregometri og væskestrømcytometri. Hovedfunnet ved dette syndromet er arterielle og venøse tromboser der hyperaggregeringen reduseres ved bruk av acetylsalisylsyre (80-100 mg daglig) (1). Dette syndromet og seronegativt antifosfolipidsyndrom ble vurdert på grunn av residiverende og alvorlig trombosering, og acetylsalisylsyre ble kombinert med warfarin. Trombosene hos vår pasient progredierte også etter oppstart av acetylsalisylsyre, og på grunn av manglende effekt av denne ble klebrig blodplate-syndrom vurdert som usannsynlig. Pasienten hadde gjentatte alvorlige arterielle og venøse tromboser, og vi vurderte det kliniske forløpet til å være forenlig med katastrofalt antifosfolipidsyndrom, den alvorligste formen for antifosfolipidsyndrom. Tilbakevendende tromboser i større arterier og vener samt trombotisk mikroangiopati talte for katastrofalt antifosfolipidsyndrom.

Pasienten ble vurdert av revmatolog seks uker etter første innleggelse og antifosfolipidantistoffsyndrom ble vurdert som ikkeaktuelt på grunn av negative antistoffer og fravær av trombocytopeni.

Diagnosen myokarditt ble revurdert sju uker etter første innleggelse og forandret til funn forenlig med hjerteinfarkt etter at ekkokardiografifunn senere viste transmurale forandringer $i$ lateralveggen av venstre ventrikkel med nedsatt kontraktilitet $i$ dette området. De forstørrede lymfeknutene i mediastinum var fortsatt uavklarte, og vår arbeidshypotese var lungeneoplasi. Pasienten ble vurdert av lungelege under oppholdet og henvist til lungepoliklinikk og til 
positronemisjonstomografi (PET) med spørsmål om malignitet $i$ lunger eller mulige metastaser $i$ binyrene. Pasienten ble utskrevet til ny rehabiliterende behandling, med warfarin og acetylsalisylsyre med diagnosene embolisuspekte hjerneinfarkter, hjerteinfarkt, miltinfarkt og forstørrede lymfeglandler med ukjent malignitetspotensial i mediastinum.

Vel tre måneder etter sykdomsstart og tolv dager etter utskrivning fra rehabiliterende behandling til hjemmet ble pasienten innlagt i medisinsk avdeling på grunn av smerter $i$ venstre glutealregion og lår med økt konsistens og omfangsøkning på $6,4 \mathrm{~cm}$ i låret. INR-verdien var 2,3, D-dimer var $>20 \mathrm{mg} / \mathrm{l}$ (normalt 0,00-0,50). Ultralyd av venstre underekstremitet og CT av bekkenvener viste trombemasser $i v$. femoralis, $v$. iliaca interna og en mindre trombe $i v$. cava inferior $i$ nivå med nyrevenene. Pasienten ble behandlet med kateterdirigert trombolyse i tre dager og ballongdilatasjon av en stenose distalt $i$ v. iliaca. Warfarin ble deretter erstattet med intravenøs dalteparin på grunn av akutt dyp venetrombose under pågående warfarinbehandling med INR-verdi i målområdet og sterk mistanke om neoplasi.

Ny CT av thorax viste uendret størrelse av lymfeknuter i mediastinum, men en liten fortetning i høyre lunges overlapp. Ultralydbronkoskopi med finnålsaspirasjon fra lymfeknutestasjon 4 og $7 \mathrm{i}$ mediastinum viste lungekreft i form av et ikke-småcellet karsinom (mucinøst adenokarsinom). PET med fluorodeoksyglukose som isotop bekreftet tumorlokalisasjonen og avkreftet metastasering til binyrene, slik at tumorklassifiseringen ble T1N2MO (T1 er tumor $\leq 3 \mathrm{~cm}$ i største dimensjon uten innvekst $i$ omkringliggende vev, N2 er spredning til to lymfeknuter i mediastinum på samme side som hovedtumor, og $\mathrm{MO}$ er ingen fjernmetastasering).

Operativ behandling av primærtumor i lungen ble vurdert, men til tross for kombinasjonsbehandling med dalteparin og acetylsalisylsyre fikk pasienten i påvente av operasjon akutt venstre hemiparalyse, forverring av kognitiv svikt og ble helt pleietrengende. Hun hadde $D$-dimer $>20 \mathrm{mg} / \mathrm{l}$ (normalt 0,00-0,50) og troponin-T $3722 \mathrm{ng} / \mathrm{l}$ (normalt < 15). MR av hjernen viste et stort infarkt i høyre a. cerebri medias forsyningsområde (fig 2). Pasienten ble tverrfaglig vurdert som inoperabel på grunn av et aggressivt forløp med raskt tilbakevendende og multiple organtromboser. Risikoen for nye tromboemboliske hendelser som følge av perioperativ seponering av antikoagulasjonsbehandling ble vurdert som høyere enn den mulige operative nytten. Hun ble utskrevet til sykehjem og fikk palliativ strålebehandling mot mediastinum og høyre fossa supraclavicularis på grunn av infiltrative lymfeknuter subcarinalt, pretrakealt og i øvre høyre mediastinum. Som komplikasjon til hjerneinfarktene utviklet hun epilepsi. Klopidogrel ble kombinert med dalteparin og acetylsalisylsyre på grunn av akutt hjerteinfarkt med ST-segmentelevasjon under denne innleggelsen. Til tross for aggressiv antikoagulasjonsbehandling rapporterte datteren senere om en forbigående episode hvor det paretiske venstre beinet ble smertefullt, hvitt og kaldt, suspekt på perifer arteriell emboli. Ett år etter sykdomsdebut døde pasienten av hjerte- og lungesvikt betinget av betydelig tumorvekst. Autopsi ble ikke utført.

\section{Diskusjon}

Hos vår pasient ga kliniske funn og forløpet med raskt tilbakevendende arterielle og venøse tromboser og embolier mistanke om katastrofalt antifosfolipidsyndrom. Dette kan opptre ved kreft, og kombinasjonen med adenokarsinom i lungene er beskrevet (2). Hos vår pasient var trombocyttallene normale og lupusantikoagulant-, antifosfolipid- og antikardiolipinantistoffene forble negative.

Vår pasient hadde et mucinøst adenokarsinom i høyre lunge som forårsaket det invalidiserende forløpet med raskt tilbakevendende arteriovenøse tromboser, til tross for tidlig antikoagulasjonsbehandling og platehemming. Kreftmarkører og omfattende bildeundersøkelser ga ikke sikre holdepunkter for kreftsykdom, selv om funnet av lymfeknutesvulst i mediastinum ga en begrunnet mistanke. Endelig kreftdiagnose ble først stilt fire og en halv måneder etter første innleggelse.

Trombosesykdom sekundært til kreft ble beskrevet av Armand Trousseau allerede i 1865 , og kombinasjon av disse to tilstandene kalles Trousseaus syndrom. Trousseau viste at venøs tromboflebitt kan være første tegn på mucinøse adenokarsinomer i lungene, ventrikkel og pancreas. Definisjonen av Trousseaus syndrom ble i 1977 utvidet til å omfatte også kronisk disseminert intravaskulær koagulasjon assosiert med trombotisk mikroangiopati, ikke-bakteriell trombotisk endokarditt på aorta- eller mitralklaff og arterielle tromboser (3). Tilbakevendende arteriovenøse tromboser ved kreft er tidligere beskrevet $i$ Tidsskriftet hos en pasient med mucinøst adenokarsinom i ventrikkelen (4).

En retrospektiv studie av 5106 pasienter innlagt $i$ en slagenhet med første gangs hjerneinfarkt viste at kreftsykdom ble påvist hos 24 pasienter $(0,4 \%)$. Av disse 24 ble kreftsykdom påvist etter det første hjerneinfarktet hos fire pasienter, mens 20 pasienter fikk kreftdiagnosen etter å ha fått et nytt slag innen fire måneder fra det første. 19 av 24 pasienter døde, median overlevelsesrate var på 58 dager etter hjerneinfarktet (5). Lungekreft og brystkreft var de hyppigste kreftformene (5).

En studie av 96 kreftpasienter med verifisert hjerneinfarkt viste at lungekreft var den dominerende krefttypen ( $30 \%)$, etterfulgt av primær hjernekreft $(9 \%)$ og prostatakreft (9\%) (6). Pasientene hadde en median overlevelsestid på 4,5 måneder etter hjerneinfarktet (6). En prospektiv studie av 842 pasienter med dyp venetrombose behandlet med antikoagulasjon (lavmolekylært heparin etter-

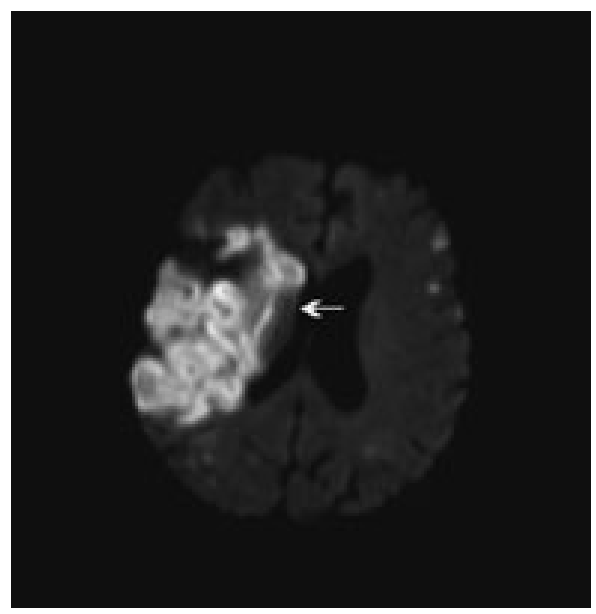

Figur 2 Diffusjonsvektet MR tre måneder etter første innleggelse viser et nytt ferskt hjerneinfarkt (pil) i høyre arteria cerebri medias forsyningsområde

fulgt av warfarin) inkluderte 181 individer med kjent kreftsykdom. Man fant at risikoen for nye venetromboser innen ett år var betydelig høyere hos pasientene med kreft enn hos de øvrige pasientene $(20,7 \%$ versus $6,8 \%$ ). Risikoen for større blødning under antikoagulasjonsbehandling var også høyere i kreftgruppen (12,4\% versus 4,9\%) (7).

En randomisert studie av 676 kreftpasienter med førstegangs venøs trombose viste at subkutan injeksjon av et lavmolekylært heparin (dalteparin) var mer effektivt enn warfarin og at frekvensen av residivtrombose var halvert hos pasienter som fikk dalteparin $(9 \%)$ sammenliknet med pasienter som fikk warfarin (17\%) (8). Ifølge amerikanske retningslinjer er lavmolekylært heparin anbefalt behandling hos pasienter med kreft og tromboser i 3-6 måneder eller lenger ved vedvarende tumoraktivitet (9).

\section{Konklusjon}

Kreftutredning bør gjøres hos slagpasienter ved tidlig tilbakevendende tromboser og dårlig respons på antikoagulasjonsbehandling og platehemming. Særlig kombinasjonen av arterielle og venøse tromboser bør gi mistanke om kreft hvis annen årsak ikke påvises. PET-helkroppsskanning og operasjon bør overveies tidligst mulig. Hos vår pasient ble risikoen for nye tromboemboliske hendelser vurdert som høyere enn mulig nytte av operativ behandling. Trombotisk sykdom ved kreft kan ha et svært aggressivt forløp og kan i seg selv være invalidiserende.

Pasientens pårørende har gitt samtykke til at artikkelen blir publisert. 


\section{Mirza Jusufovic (f. 1980)}

er assistentlege ved Nevrologisk avdeling, Oslo universitetssykehus, Rikshospitalet og har tidligere vært assistentlege ved Nevrologisk avdeling. Haukeland universitetssykehus. Ingen oppgitte interessekonflikter.

\section{Lars Thomassen (f. 1947)}

er spesialist i nevrologi og overlege ved Nevrologisk avdeling, Haukeland universitetssykehus. Ingen oppgitte interessekonflikter.

\section{Anette Storstein (f. 1966)}

er spesialist i nevrologi og overlege ved Nevrologisk avdeling, Haukeland universitetssykehus. Ingen oppgitte interessekonflikter.

\section{Svein Rotevatn (f. 1957)}

er spesialist i indremedisin og i hjertesydommer og er overlege ved Hjerteavdelingen, Haukeland universitetssykehus.

Ingen oppgitte interessekonflikter.

\section{Sverre Lehmann (f. 1966)}

er spesialist i indremedisin og i lungesykdommer og er seksjonsoverlege ved Lungeavdelingen, Haukeland universitetssykehus. Ingen oppgitte interessekonflikter

\section{Ulrike Waje-Andreassen (f. 1962)}

er spesialist i nevrologi og overlege ved Nevrologisk avdeling, Haukeland universitetssykehus Ingen oppgitte interessekonflikter.

\footnotetext{
Litteratur

1. Mammen EF. Sticky platelet syndrome. Semin Thromb Hemost 1999; 25: 361-5.

2. Miesbach W. Malignancies and catastrophic antiphospholipid syndrome. Clin Rev Allergy Immuno 2009. 36: $91-7$

3. Sack GH Jr, Levin J, Bell WR. Trousseau's syndrome and other manifestations of chronic disseminated coagulopathy in patients with neoplasms: clinical, pathophysiologic, and therapeutic features. Medicine (Baltimore) 1977; 56: 1-37.

4. Lossius A, Elvsåshagen T, Taubøll E. En 58 år gammel kvinne med hjerneslag, troponinstigning
}

og hyperkoagulabilitet. Tidsskr Nor Legeforen 2008: 128 : $706-8$

5. Taccone FS, Jeangette SM, Blecic SA. First-ever stroke as initial presentation of systemic cancer. J Stroke Cerebrovasc Dis 2008; 17: 169-74.

6. Cestari DM, Weine DM, Panageas KS et al. Stroke in patients with cancer: incidence and etiology. Neurology 2004; 62: 2025-30.

7. Prandoni P, Lensing AW, Piccioli A et al. Recurrent venous thromboembolism and bleeding complications during anticoagulant treatment in patients with cancer and venous thrombosis. Blood 2002; 100: $3484-8$.

8. Lee AY, Levine MN, Baker RI et al. Low-molecularweight heparin versus a coumarin for the prevention of recurrent venous thromboembolism in patients with cancer. N Engl J Med 2003; 349 $146-53$.

9. Kearon C, Kahn SR, Agnelli G et al. Antithrombotic therapy for venous thromboembolic disease: American college of chest physicians evidence-based clinical practice guidelines ( $8^{\text {th }}$ edition). Chest 2008; 133 (suppl): 454S-545S.

Mottatt 4.6. 2010, første revisjon innsendt 1.11. 2010, godkjent 6.1. 2011. Medisinsk redaktør Lars Frich.

\section{Kommentar}

\section{Den diagnostiske jakten}

Historien om den 61 år gamle kvinnen med tilbakevendende arteriovenøse tromboser kan leses og fortolkes på flere måter. Først og fremst er kasuistikken en instruktiv medisinskfaglig beretning om det paramaligne fenomen. Sykehistorien og de kliniske og parakliniske funnene samt de omfattende differensialdiagnostiske overveielsene formidles detaljert og pedagogisk. En leser av Jusufovic' og medarbeideres artikkel må ha gode generelle medisinske kunnskaper «for å henge med i svingene». Jakten på underliggende malignitet ble gjennomført nærmest som et detektivarbeid i samvirke mellom mange ulike legespesialister. Først fire og en halv måned etter første innleggelse ble gåten løst, men da var det dessverre for sent å tilby kurativ behandling.

Kasuistikken kan også leses med et helt annet perspektiv, nemlig som en fortelling om hvor kompleks, teknologisk og kostnadskrevende moderne medisin kan være. I løpet av innleggelsene på universitetssykehuset møtte pasienten leger fra minst 12 forskjellige fagspesialiteter (øye, nevrologi, radiologi, kardiologi, lunge, anestesi, revmatologi, øre-nese-hals, hud, endokrinologi, nukleærmedisin og onkologi). I tillegg til en mengde mer eller mindre spesialiserte undersøkelser av blodet ble det foretatt en lang rekke teknologisk baserte organundersøkelser. Ultralydundersøkelse av blodårer i ulike gebet ble nok utført ved hver innleggelse og ekkokardiografi minst fire ganger. Med CTog MR- maskiner skannet man hjernen, halsen, thorax, abdomen, bekken, arterier og vener. Det ble utført beinmargsbiopsi, mammografi, spinalvæskeanalyse, bronkoskopi med biopsi og positronemisjonstomografi samt terapeutisk kateterbasert venøs rekanalisering og palliativ radioterapibehandling.

I ettertid kan man selvfølgelig reflektere over hvorvidt den omfattende utredningen og ressursbruken var «hensiktsmessig og riktig», ikke minst i og med at forfatterne selv refererer til litteratur som viser at median overlevelse ved påvist kreft etter hjerneinfarkt er på relativt få måneder (1). Man kan videre spørre om legen alltid skal tilstrebe «å komme til bunns»? Og hva med pasienten selv, med hvilken opplevd livskvalitet og med hvilken grad av kognitiv forståelse gjennomførte hun sykehusinnleggelsene? Kunne hun selv i rimelig grad vurdere om utredningen samlet sett var til hennes eget beste? Som Per Fugelli skrev i en aviskronikk etter selv å ha vært alvorlig syk: «Det er ikke sykdommen, som et fremmedlegeme i kroppen, som er legens oppdrag. Legens oppgave er å helbrede, lindre og trøste det mennesket sykdommen bor i.» (2).

Hva kan man så lære av denne pasienthistorien? For det første viser den hvor krevende og vanskelig medisinsk diagnostikk kan være, ikke minst i det nevrologiske fagfeltet. For det andre illustrerer historien hvor avhengig moderne medisin er blitt av teknologi. For legen representerer denne utviklingen en stadig større utfordring: det å benytte teknologien på en balansert måte og samtidig aldri glemme at det viktigste i legerollen fortsatt er den direkte kontakten med pasienten.

\section{Christian Georg Lund}

christian.lund@rikshospitalet.no

Nevrologisk avdeling

Nevroklinikken

Oslo universitetssykehus, Rikshospitalet

Christian Georg Lund (f. 1961) er spesialist i nevrologi og overlege ved Nevrologisk avdeling. Ingen oppgitte interessekonflikter.

\section{Litteratur}

1. Cestari DM, Weine DM, Panageas KS et al. Stroke in patients with cancer: incidence and etiology. Neurology 2004: 62: 2025-30

2. Fugelli P. Engangsleger. Aftenposten 3.2.2011: 4

Mottatt 18.5. 2011, første revisjon innsendt 26.5 2011, godkjent 30.5. 2011. Medisinsk redaktør Lars Frich. 